Proceedings

\title{
Study of the Influence of Picking Frequency and Drying Mate- rials on Moulds and Aflatoxins Occurrence in Cashew Nuts from Côte d'Ivoire
}

\author{
Koffi Yao Stephane 1, Kouadio James Halbin 1,2,*
}

Citation: Stephane, K.Y; Halbin , K.J.; Study of the Influence of Picking Frequency and Drying Materials on Moulds and Aflatoxins Occurrence in Cashew Nuts from Côte d'Ivoire . Proceedings 2021, 65, x. https://doi.org/10.3390/xxxxx

Received: 3 November 2020

Accepted: 7 January 2021

Published: 14 January 2021

Publisher's Note: MDPI stays neutral with regard to jurisdictional claims in published maps and institutional affiliations.

Copyright: (c) 2021 by the authors. Submitted for possible open access publication under the terms and conditions of the Creative Commons Attribution (CC BY) license (http://creativecommons.org/licenses /by/4.0/).
1 Research Group of Crop Production Quality Management, Laboratory of Agrovalorisation, UFR Agroforesterie, Jean Lorougnon Guédé University, BP 150 Daloa, Côte d'Ivoire

2 Laboratory of (Bio) Toxicology and Industrial Hygiene, DPPSST, CNPS 01 B.P. 317 Abidjan, Côte d'Ivoire

* Correspondence: jameshalbink@yahoo.fr

\begin{abstract}
The aim of the present study was to evaluate the impact of picking frequency and dryers materials on fungal infection and aflatoxins content in cashew nuts produced in Côte d'Ivoire. Some cashew nuts collected after a delay of 2, 3 and 7 days on the ground, were sun-dried on racks-table, tarpaulin and cemented area to a moisture content of $8 \%$. After 6 months of storage, 18 samples $(3 \mathrm{~kg}$ of each) of cashew nuts were collected and the fungal infection and aflatoxins content were evaluated using standard methods. Our results revealed that the rate of fungal infection evolved in keeping with the frequency of nuts picking. Thus, the rate of fungal infection was $5.7 \%$ at 2 days of frequency of nuts picking, $22.7 \%$ at 3 days and $54.6 \%$ at 7 days respectively. Proportionally, the loss rates were $1.85,4.73$ and $11.03 \%$. The dryers had no significant effect on the infection and loss rates with corresponding values ranging from 24.49 to $31.45 \%$ and 5.41 to $10.32 \%$ respectively. A total of 12 genera and 148 fungal species were isolated and identified. The genus Aspergillus represented by Aspergillus niger (71.78\%), Aspergillus flavus (4.29\%), Aspergillus fumigatus (2.45\%) and Aspergillus sp (1.84\%) was the most preponderant. Although aflatoxin levels were marginal, they can reach $0.34 \mu \mathrm{g} / \mathrm{kg}$ with the 7 -days pickup time. This aflatoxin level is related to the presence of aflatoxin B1 $(0.29 \mu \mathrm{g} / \mathrm{kg})$. The drying supports namely tarpaulins or cemented areas seemed to influence the level of aflatoxins secretion. Taken together, our results suggested that the frequency of cashew nuts picking was a critical control point in value chain for both fungal infection and aflatoxins contamination. In certain way, the racks-table seemed to be suitable drying support to avoid aflatoxins contamination.
\end{abstract}

Keywords: cashew nuts; picking frequency; dryers; Aspergillus sp; aflatoxins

\section{Introduction}

Anacardium species are native to tropical America [1] and have significant economic importance throughout the world [2]. The cashew tree represents for Africa which provides $50 \%$ of the world's supply of raw cashew nuts, a great opportunity through the export of its nuts [3], [4]. Since 2015, Côte d'Ivoire has positioned itself as the first country to provide this commodity in terms of tonnage of nuts. Thus, with its 350,000 producers located mainly in the North, North-West and North-East regions, Côte d'Ivoire produces on average more than 700,000 tonnes of nuts per year representing a rate of $21 \%$ of the World's offer [5]. Despite the enormous potential for cashew revenue in Côte d'Ivoire, the cashew production is characterized not only by low-yields, but also by a less competitive quality of nuts internationally [5]. It had been also reported that the diversity of ecological regions combined with poor harvest and post-harvest practices are a major constraint to improve the quality of nuts produced [6], [7], [8]. There is no data on the incidence of 
practices of Ivorian producers on cashew nuts quality in Côte d'Ivoire namely fungal infection rate and aflatoxins occurrence. In our previous study (data no published), we have found a veritable disparity in agricultural practices according to cashew nut production regions in Côte d'Ivoire and these practices remained rudimentary. Indeed, the process of cashew production in Côte d'Ivoire may be improved at level of all stages namely collection (harvest), post-harvest (drying, storage and transport). The goal of the present study was to study the influence of picking frequency and drying materials on molds and aflatoxins occurrence in cashew nuts from Côte d'Ivoire in order to improve their quality.

\section{Material and methods}

Cashews fruits were collected at different soil residence times namely 2, 3 and 7 days and the nuts were dried until a water content of $8 \%$ on three different support namely on tarpaulin (A), rack (B) and cemented area (C) (Figure 1). These nuts were bagged in jute bags and stored on pallets in a warehouse at room temperature of $31{ }^{\circ} \mathrm{C} \pm 2{ }^{\circ} \mathrm{C}$ and $77 \%$ $\pm 9 \%$ relative humidity for 6 months. A total number of 12 coded samples of $3 \mathrm{~kg}$ each were packaged in hermetically sealed plastic bags to avoid any contact with the outside and transported to the laboratory on the one hand for physical analyzes and for mycological and mycotoxins analyzes (assays of mycotoxins and search for toxinogenic molds) on the other hand.
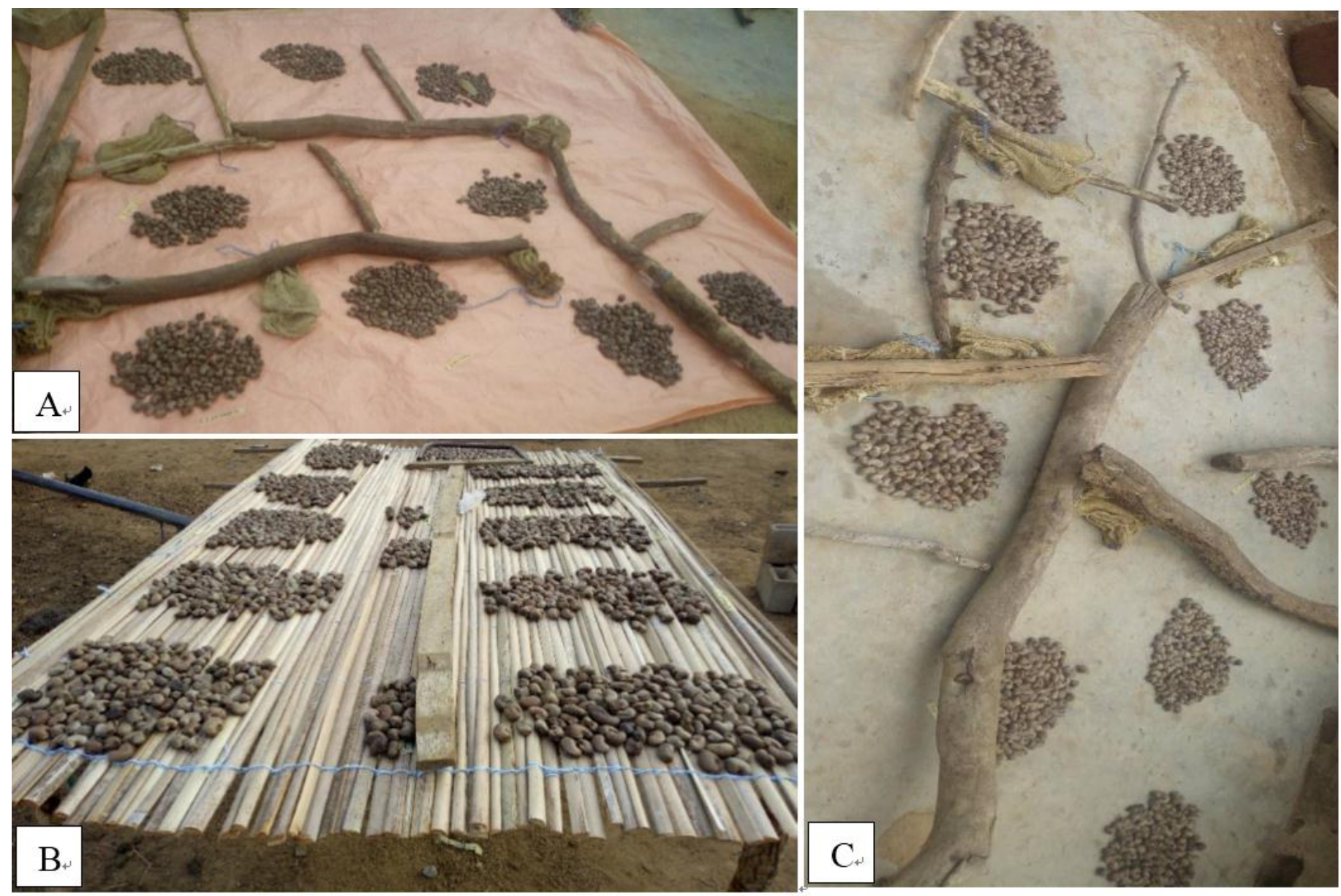

Figure 1. Picture showing the drying of cashew nuts on tarpaulin (A), rack (B) and cemented area (C) during the experimental study.

\subsection{Cashew nuts analyses}

The cashew nuts infection rate (IR) was calculated according to this formula [9], [10]: 


$$
I R(\%)=\frac{(\text { Number of infected nuts })}{\text { Total number of nuts })} \times 100
$$

The loss rate (Lr) of cashew nuts was obtained from the following formula [9], [10] :

$$
\operatorname{Lr}(\%)=\frac{u n N+\left(\frac{1}{2} p u N\right)}{(\text { Total number of nuts })} \times 100
$$

Fungal flora of cashew samples was isolated by the modified blotter method [11] using macroscopic (colony colour, morphology and size) and microscopic (conidia morphology and size) characteristics. The relative densities (Rd) of molds were also calculated according to the following formula [12]:

$$
R d(\%)=\frac{\text { Number of isolated species genus }}{\text { Total number of isolated fungi }} \times 100
$$

Aflatoxins content was determined according to AOAC (2005) methods High Performance Liquid Chromatography coupled with fluorimetric detector.

\section{Results and discussion}

\subsection{Cashew nut infection rate}

The highest infection rates were $54.6 \pm 35.43 \%$ in nuts collected 7 days after dropping and $22.7 \pm 9.39 \%$ in nuts with a 3 days collection time (Table 1). The pick-up time therefore influences the nuts colonization by molds and the suitable time of nuts collection was 2 days $(5.7 \pm 5.74 \%)$. Despite the highest infection rate found with tarpaulin $(37.66 \pm 6.20 \%)$ material and the lowest, in nuts dried on a rack $(24.49 \pm 0.88 \%)$, the impact of the dryers seemed failure (Table 2).

Table 1. Variation of the infection rate according to the time devoted to collect the nuts.

\begin{tabular}{cccc}
\hline \multirow{2}{*}{ Pick up delay } & \multicolumn{3}{c}{ Infection rate (\%) } \\
\cline { 2 - 4 } & Minimum & Maximum & Average \\
\hline 2 days & 0.0 & 11.5 & $5.7 \pm 5.74^{\mathrm{a}}$ \\
\hline 3 days & 13.3 & 32.1 & $22.7 \pm 9.39^{\mathrm{ab}}$ \\
\hline 7 days & 19.1 & 90.0 & $54.6 \pm 35.43^{\mathrm{c}}$ \\
\hline
\end{tabular}

For a given column, the means followed by the same letter are not significantly different according to Fisher's LSD test at $5 \%$. The numbers into brackets indicate the total number of nuts sampled.

Table 2. Variation in the infection rate depending on the drying materials.

\begin{tabular}{cccc}
\hline \multirow{2}{*}{ Drying rack } & \multicolumn{3}{c}{ Infection rate (\%) } \\
\cline { 2 - 4 } & Minimum & Maximum & Average \\
\hline Cimented area & 44,87 & 18,02 & $31,45 \pm 13,42^{\text {a }}$ \\
\hline Tarpaulin & 31,45 & 43,86 & $37,66 \pm 6,20^{\text {a }}$ \\
\hline Rack table & 25,37 & 23,61 & $24,49 \pm 0,88^{\text {a }}$ \\
\hline
\end{tabular}

For a given column, the means followed by the same letter are not significantly different according to Fisher's LSD test at 5\%. The numbers into brackets indicate the total number of nuts sampled.

\subsection{Loss rate}

According to Table 3 Nuts collected 2 days after the fall of the fruit recorded the lowest loss rate, with an average of $1.85 \%$ following by those collected 3 days after the fall of the fruit $(4.73 \%)$. Nuts that were collected after 7 days on the ground were the nut category with the highest loss rate $(11.03 \%)$. With regard to the drying process (Table 4$)$, the 
racks seemed suitable with significantly low loss rate $(5.41 \%)$ in contrast to cemented area and the tarpaulin.

Table 3. Variation in loss rate by time of nut collection.

\begin{tabular}{cccc}
\hline \multirow{2}{*}{ Pick up delay } & \multicolumn{3}{c}{ Loss rate (\%) } \\
\cline { 2 - 4 } & Minimum & Maximum & Average \\
\hline 2 days & 0,00 & 3,70 & $1,85 \pm 1,85^{\mathrm{a}}$ \\
\hline 3 days & 1,06 & 5,17 & $4,73 \pm 0,44^{\mathrm{ab}}$ \\
\hline 7 days & 4,32 & 17,74 & $11,03 \pm 6,71^{\mathrm{c}}$ \\
\hline
\end{tabular}

For a given column, the averages followed by the same letter are not significantly different according to Fisher's. 5\% LSD test. The numbers in brackets indicate the total number of nuts sampled.

Table 4. Variation in the rate of loss according to the drying support of the nuts.

\begin{tabular}{cccc}
\hline \multirow{2}{*}{ Type of dryer } & \multicolumn{3}{c}{ Loss rate (\%) } \\
\cline { 2 - 4 } & Minimum & Maximum & Average \\
\hline Cimented area & 5,81 & 13,82 & $9,81 \pm 4,00^{\text {a }}$ \\
\hline Tarpaulin & 7,95 & 12,68 & $10,32 \pm 2,36^{\mathrm{a}}$ \\
\hline Rack & 5,38 & 5,45 & $5,41 \pm 0,03^{\mathrm{b}}$ \\
\hline
\end{tabular}

For a given column, the averages followed by the same letter are not significantly different according to Fisher's. 5\% LSD test. The numbers in brackets indicate the total number of nuts sampled.

\subsection{Cashew nut mycoflora}

A total of 148 fungal strains were isolated from all the nuts collected and 12 fungal genera were identified with in decreasing order of predominance (Figure 2): Aspergillus (80.37\%), Chrysonilia (6.75\%), Rhizopus (3.07\%), Fusarium (1.84\%), Trichoderma (1.84\%), Absidia $(1.23 \%)$, Cladosporium (1.23\%), Curvularia (1.23\%), Alternaria (0.61\%), Gliomatix (0.61\%), Penicillium $(0.61 \%)$ and Myrothecium (0.61\%). These findings were supported by the reported previously in cashew nuts from Benin, West Africa country [13] where seven species of black Aspergilli were isolated namely A. tubingensis (44\%), A. niger (32\%), A. brasiliensis (10\%), A. car-bonarius (8.7\%), A. luchuensis (2.7\%), A. aculeatus (2\%) and A. aculeatinus $(0.7 \%)$.

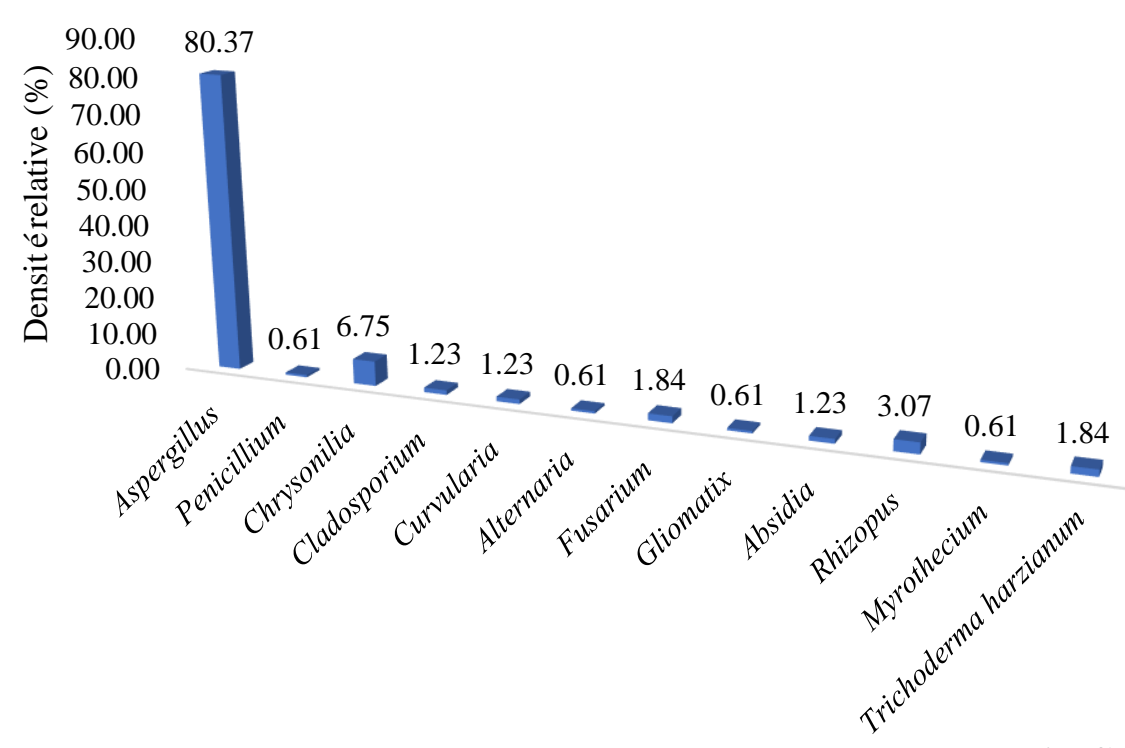

Micoflora

Figure 2. Relative densities of the individual mould types in all cashew samples tested. 


\subsection{Aflatoxinogenic mycoflora of cashew nuts according to the collection time}

Figure 3 showed that all samples analysed were found to be contaminated with the potentially aflatoxinogenic mould: Aspergillus flavus. This fungal species was strongly isolated $(3.05 \%)$ in the nuts collected 3 days after the fruit fell. The number of isolates was estimated at $0.75 \%$ and $1.63 \%$ in nuts with a collection time of 2 days and 7 days respectively.

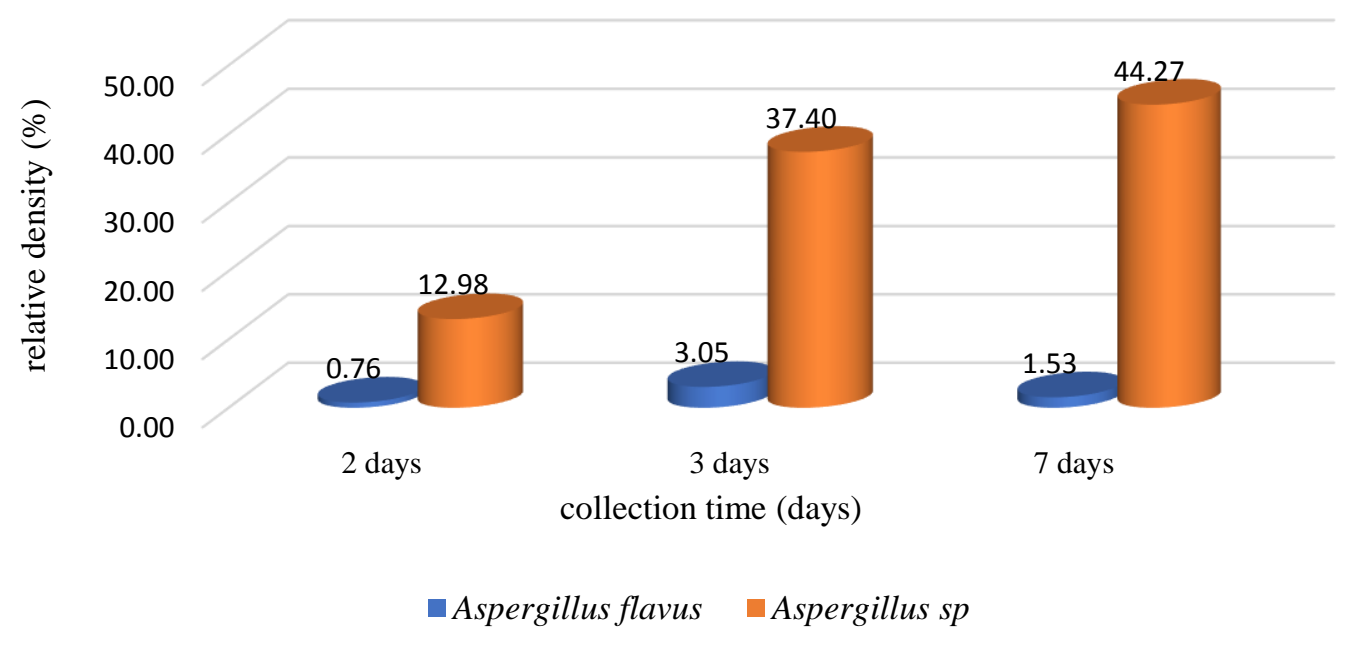

Figure 3. Density of potentially aflatoxinogenic moulds as a function of the cashew nuts picking time.

\subsection{Aflatoxin content of samples collected at different collection times}

According to Table 5, when the nuts were collected 2 days after the fruit fell, no contamination was detected. However, they were detected for a collection time of 3 and 7 days. The aflatoxin levels of nuts collected every 3 days (AFB1 $=0.18 ; \mathrm{AFT}=0.29$ ) were significantly lower than those of nuts collected every 7 days (AFB1=0.29; AFT=0.34). Probably, an extended harvest time in the field could increase the exposure of the nuts to attack by various pests and could thus lead to greater losses during storage [14], [15].

Table 5. Average level of aflatoxin contamination according to the time of nut collection.

\begin{tabular}{cccccc}
\hline \multirow{2}{*}{ Pick up delay } & \multicolumn{5}{c}{ level of aflatoxin $\left(\boldsymbol{\mu g} \cdot \mathbf{k g}^{-1}\right)$} \\
\cline { 2 - 6 } & AFB1 & AFG2 & AFG1 & AFB2 & AFT \\
\hline 2 days & ND & $<$ L.Q & $<$ L.Q & $<$ L.Q & N.D \\
\hline 3 days & $0,18 \pm 0,09^{\text {a }}$ & $<$ L.Q & $<$ L.Q & $<$ L.Q & $0,21 \pm 0,27^{\text {a }}$ \\
\hline 7 days & $0,29 \pm 0,13^{\text {b }}$ & $<$ L.Q & $<$ L.Q & $<$ L.Q & $0,34 \pm 0,41^{\text {b }}$ \\
\hline
\end{tabular}

AFB1: Aflatoxin B1; AFB2: Aflatoxin B2; AFG1: Aflatoxin G1; AFG2: Aflatoxin G2; AFT: Total Aflatoxin; n:. Number of samples analysed. In the AFT column, the values followed by the same letter are not significantly different according to Fisher's 5\% LSD test.

\subsection{Aflatoxin content of samples according to different drying materials}

The aflatoxins content of the nuts was strongly influenced by the drying materials used (Table 6) The contents of the tarpaulins are higher than those of the cemented areas ( 0.25 of AFB1 and 0.25 of AFT). No contamination was detected in nuts dried on the racks. Since, the higher levels of contamination $(0.3 \mu \mathrm{g} . \mathrm{kg}-1)$ were determined in the samples of nuts dried on the tarpaulin, this result corroborates that reported high levels of mycotoxin contamination in cocoa beans when the tarpaulin was used as a dryer [16]. 
Table 6. Average level of aflatoxins according to the drying materials.

\begin{tabular}{cccccc}
\hline \multirow{2}{*}{ Dryers } & \multicolumn{5}{c}{ level of aflatoxins $\left(\mu \mathrm{\mu g} \cdot \mathbf{k g}^{-1}\right)$} \\
\cline { 2 - 6 } & AFB1 & AFG2 & AFG1 & AFB2 & AFT \\
\hline Rack-table & N.D & N.D & N.D & N.D & N.D \\
\hline Tarpaulin & $0,25 \pm 0,38^{\text {a }}$ & $<$ L.Q & $<$ L.Q & $<$ L.Q & $0,3 \pm 0,84^{\text {a }}$ \\
\hline Cimented area & $0,1 \pm 0,12^{\mathrm{b}}$ & $<$ L.Q & $<$ L.Q & $<$ L.Q & $0,11 \pm 0,34^{\text {b }}$ \\
\hline
\end{tabular}

AFB1: Aflatoxin B1; AFB2: Aflatoxin B2; AFG1: Aflatoxin G1; AFG2: Aflatoxin G2; AFT: Total Aflatoxin; n:. Number of samples analysed. In the AFT column, the values followed by the same letter are not significantly different according to Fisher's 5\% LSD test.

\section{Conclusion}

Cashew nuts produced according to the 2 , and 7 day pickup times and dried on different supports are susceptible to contamination by fungi and aflatoxins. Mushrooms are dominated by the genus Aspergillus, which is recognised as a toxin producer. The aflatoxin levels detected, whatever the collection time, have remained below the standards set for cashew nuts. However, the nuts collected after 7 days after they have fallen, contain higher levels and drying with the tarpaulin would also favour this production.

\section{References}

1. V. de C. Nilo Bitu et al., «Ethnopharmacological study of plants sold for therapeutic purposes in public markets in Northeast Brazil », Journal of Ethnopharmacology, vol. 172, p. 265-272, août 2015, doi: 10.1016/j.jep.2015.06.022.

2. R. M. Schweiggert et al., " Carotenoids, carotenoid esters, and anthocyanins of yellow-, orange-, and red-peeled cashew apples (Anacardium occidentale L.) », Food Chemistry, vol. 200, p. 274-282, juin 2016, doi: 10.1016/j.foodchem.2016.01.038.

3. E. Dedehou, J. Dossou, et M. M. Soumanou, «Etude diagnostique des technologies de transformation de la pomme de cajou en jus au Bénin », International Journal of Biological and Chemical Sciences, vol. 9, no 1, Art. no 1, juill. 2015, doi: 10.4314/ijbcs.v9i1.

4. D. K. Issaka, « Production de noix de cajou au Bénin: état des lieux et perspectives pour 2019», p. 22, 2019.

5. H. Ducroquet, P. Tillie, K. Elouhichi, et Y. P. S. Gomez, « L'agriculture de la Côte d'Ivoire à la loupe: Etat des lieux des filières de production végétales et animales et revue des politiques agricoles », Publications Office of the European Union, EUR - Scientific and Technical Research Reports, 2017. Consulté le: juin 27, 2020. [En ligne]. Disponible sur: https://publications.jrc.ec.europa.eu/repository/handle/111111111/51249.

6. C. Rabany, N. Rullier, et P. Ricau, «THE AFRICAN CASHEW SECTOR IN General trends and country profiles - PDF Free Download ». RONGEAD, 2015, Consulté le: déc. 21, 2020. [En ligne]. Disponible sur: https://docplayer.net/41959173-Theafrican-cashew-sector-in-general-trends-and-country-profiles.html.

7. F. Waliyar, M. Osiru, H. Sudini, et S. M. C. Njoroge, « Reducing Aflatoxins in Groundnuts through Integrated Management and Biocontrol », in Aflatoxins - finding solutions for improved food safety, International Food Policy Research Institute, 2013, p. 1-2.

8. M. Blanc, «QUALITE SANITAIRE DES ALIMENTS ET DEVELOPPEMENT Nouvelles exigences en matière de sécurité sanitaire dans le commerce international des produits agricoles et agro-alimentaires. Incidences pour les pays $\mathrm{d}^{\prime} \mathrm{Afrique}$ exportateurs de produits oléagineux », OCL, vol. 8, no 3, Art. no 3, mai 2001, doi: 10.1051/ocl.2001.0246.

9. C. K. Kouakou et al., « Agro-morphological characterization of cashew (Anacardium occidentale L.) ecotypes from NorthCentral of Côte d'Ivoire. ", Fruits, vol. 73, no 5, 2018.

10. G. Dongmo, J. Djeugap Fovo, N. Fenohi, N. Kenfack, R. Takuete, et P. Teguefouet, « Contribution à l'identification des champignons de post-récolte associés aux amandes de Ricinodendron heudelotii et Garcinia kola collectées dans les Hauts Plateaux de l'Ouest Cameroun », International Journal of Biological and Chemical Sciences, vol. 11, p. 1840, déc. 2017, doi: 10.4314/ijbcs.v11i4.33.

11. J. Francisca et al., « African Journal of Agricultural Research Sanitary analysis, transmissibility and pathogenicity of fungi associated with cashew nuts », African Journal of Agricultural Research, vol. 12, p. 229-236, févr. 2017, doi: 10.5897/AJAR2016.11719.

12. K. E. Damann Jr., "Atoxigenic Aspergillus flavus biological control of aflatoxin contamination: what is the mechanism? », World Mycotoxin Journal, vol. 8, no 2, p. 235-244, janv. 2015, doi: 10.3920/WMJ2014.1719.

13. Lamboni Y, Nielsen KF, Linnemann AR, Gezgin Y, Hell K, Nout MJR, et al. (2016) Diversity in Secondary Metabolites Including Mycotoxins from Strains of Aspergillus Section Nigri Isolated from Raw Cashew Nuts from Benin, West Africa. PLoS ONE 11(10): e0164310. doi:10.1371/journal. pone.0164310

14. K. Hell et C. Mutegi, "Aflatoxin control and prevention strategies in key crops of Sub-Saharan Africa », AJMR, vol. 5, no 5, p. 459-466, mars 2011, doi: 10.5897/AJMR10.009. 
15. C. Borgemeister et al., « Timing of harvest in maize: effects on post harvest losses due to insects and fungi in central Benin, with particular reference to Prostephanus truncatus (Horn) (Coleoptera: Bostrichidae) », Agriculture, Ecosystems \& Environment, vol. 69, no 3, p. 233-242, juill. 1998, doi: 10.1016/S0167-8809(98)00109-1.

16. S. D. Dano et al., « Influence of Fermentation and Drying Materials on the Contamination of Cocoa Beans by Ochratoxin A », Toxins, vol. 5, p. 2311-2323, 2013, doi: 10.3390/toxins5122310. 